Web Jurnal:

http://ejournal.kemenperin.go.id/jli

\title{
Pembuatan minuman fungsional tablet effervescent dari bubuk ekstrak daun kacang tujuh jurai (Phaseolus lunatus, L.)
}

\section{Preparation of functional drinks of effervescent tablets from lima bean leaf extract powder (Phaseolus lunatus, L.)}

\section{Dini Novita Sari}

Universitas Nahdlatul Ulama Sumatera Utara

Jln. H. A. Manaf Lubis, Medan, Indonesia

e-mail: diniharjo@gmail.com

\begin{tabular}{l}
\hline INFO ARTIKEL \\
\hline Sejarah artikel: \\
Diterima: \\
28 Januari 2019 \\
Direvisi: \\
24 Mei 2019 \\
Diterbitkan: \\
28 Juni 2019
\end{tabular}

\section{Kata kunci:}

antioksidan;

ekstrak;

effervescent;

Phaseolus lunatus, L.

\begin{abstract}
ABSTRAK
Penelitian ini bertujuan untuk mengetahui pengaruh penambahan bubuk ekstrak daun kacang tujuh jurai terhadap sifat fisik dan kimia tablet effervescent. Penelitian ini menggunakan Rancangan Acak Lengkap (RAL) dengan 5 perlakuan yaitu penambahan bubuk ekstrak daun kacang tujuh jurai masing-masing 10, 15, 20, 25, dan 30\% dengan 3 kali ulangan. Pengamatan tablet effervescent meliputi pengamatan fisik : penampakan, waktu larut, kekerasan dan kerapuhan; pengamatan kimia : kadar air, pH larutan, kadar vitamin $\mathrm{C}$, aktivitas antioksidan, kadar klorofil, dan warna. Hasil penelitian menunjukkan bahwa penambahan bubuk ekstrak daun kacang tujuh jurai berpengaruh nyata terhadap ketebalan tablet, waktu larut, kerapuhan, kadar air, vitamin C, aktivitas antioksidan, kadar klorofil dan warna tablet effervescent yang dihasilkan. Penambahan bubuk ekstrak daun kacang tujuh jurai tidak mempengaruhi ukuran diameter tablet effervescent, kekerasan dan $\mathrm{pH}$.
\end{abstract}

\section{Keywords:}

antioxidants;

extracts;

effervecsent;

Phaseolus lunatus, $L$.

\begin{abstract}
This study was aimed to determine the effect of the addition of lima bean leaf extract powder on the physical chemical and properties of effervescent tablets. This study used a completely randomized design (CRD) with 5 treatments, the addition of lima bean leaf extract powder of 10,15,20,25, and 30\% with 3 replications, respectively. Tablet effervescent observations include physical observations: appearance, dissolution time, hardness and fragility; chemical observations: water content, $p H$ of the solution, vitamin $C$ level, antioxidant activity, chlorophyll content, and color. The results showed that the addition of lima bean leaf extract powder significantly affected tablet thickness, dissolution time, fragility, moisture content, vitamin $C$, antioxidant activity, chlorophyll content and effervescent tablet color produced. The addition of lima bean leaf extract powder did not affect the size of the effervescent tablet diameter, hardness and $\mathrm{pH}$.
\end{abstract}

\section{Pendahuluan}

Klorofil merupakan zat hijau daun yang terdapat pada semua tumbuhan hijau yang berfotosintesis. Sumber klorofil yang dapat dikonsumsi salah satunya yaitu tanaman kacang tujuh jurai atau kacang emas (Phaseolus lunatus, L.). Bagian tanaman kacang tujuh jurai yang dapat digunakan adalah pada daunnya. Seiring dengan berkembangnya teknologi dibidang pangan, maka pemanfaatan daun kacang ini dapat diharapkan meningkatkan nilai tambah yaitu dengan menjadikan tablet effervescent. Daun kacang tujuh jurai banyak dimanfaatkan sebagai bahan minuman, daunnya diekstrak dengan air menjadi minuman kesehatan yang biasa dikenal oleh orang Minang Sumatera Barat dengan sebutan air kacang tujuh jurai atau aia daun kacang dan diminum bersama dengan cincau hijau. 
Minuman daun kacang dibuat melalui proses penghancuran daun kacang tujuh jurai dengan perbandingan daun kacang tujuh jurai dan air yaitu 1:2, kemudian disaring sehingga mendapatkan ekstrak daun kacang. Daun kacang tujuh jurai memiliki peranan fungsional dalam kesehatan. Minuman ini diyakini oleh masyarakat Minang dapat menyembuhkan berbagai macam penyakit seperti penurun demam dan gangguan panas dalam. Pembuatannya disajikan dengan penambahan perasan jeruk nipis sebagai penambah kesegaran, pemberi flavor alami, dengan kandungan vitamin $\mathrm{C}$ yang berguna sebagai antioksidan bagi tubuh untuk membantu menjaga kesehatan sel, meningkatkan penyerapan asupan zat besi dan memperbaiki kekebalan tubuh. Kandungan vitamin C pada jeruk nipis sekitar 27 mg/100 g bahan (Nazwa dan Azrina, 2017).

Semakin pekat ekstrak yang dihasilkan maka menghasilkan warna sangat hijau, menunjukkan adanya kandungan klorofil, sehingga dengan semakin tingginya kandungan klorofil maka kadar antioksidannya juga semakin tinggi. Berbagai hasil penelitian menunjukkan bahwa klorofil mempunyai beberapa manfaat bagi kesehatan tubuh seperti merangsang sel-sel darah putih sehingga dapat memperkuat sistem kekebalan tubuh (Alsuhaibani et al., 2017). Antioksidan merupakan senyawa yang mampu memperlambat atau mencegah proses oksidasi dalam tubuh dengan kemampuan menangkap radikal bebas (Ighodaro dan Akinloye, 2018). Menurut Pourreza (2013), senyawa antioksidan adalah senyawa pemberi elektron, antioksidan sangat penting karena berkaitan dengan berfungsinya sistem imunitas tubuh.

Berdasarkan uraian diatas, maka diyakini daun kacang tujuh jurai mempunyai khasiat yang sangat unggul sebagai sumber antioksidan alami yang berasal dari klorofil daun kacang tujuh jurai. Selain dapat disajikan dalam bentuk ekstrak cair dan bubuk, ekstrak daun kacang tujuh jurai juga dapat disajikan dalam bentuk yang berbeda untuk mempermudah dalam penyajiannya, ekstrak bubuk daun kacang tujuh jurai dibuat dalam bentuk tablet effervescent, sehingga diharapkan dapat mempertahankan kandungan antioksidannya. Menurut Ipci et al. (2016), effervescent didefinisikan sebagai bentuk sediaan yang menghasilkan gelembung gas sebagai hasil reaksi kimia dalam larutan. Gas yang dihasilkan umumnya adalah karbondioksida $\left(\mathrm{CO}_{2}\right)$. Tablet effervescent merupakan alternatif pengembangan produk minuman ringan yang menarik, mudah larut dalam air, praktis dalam penyajian, menjadikan larutan yang jernih dan memberi efek sparkle atau seperti minuman soda, memberikan variasi dalam penyajian minuman tradisional juga praktis dalam penyimpanan dan transportasi dibanding minuman ringan biasa dalam bentuk cair, effervescent juga memberikan rasa yang enak karena adanya karbonat yang membantu memperbaiki rasa.

Pada penelitian pendahuluan untuk mendapatkan formulasi tablet effervescent dengan penambahan ekstrak daun kacang tujuh jurai yang telah dibubukkan dengan penambahan yang berbeda. Diperoleh hasil bahwa pada penambahan ekstrak daun kacang tujuh jurai 5\% yang dikombinasikan dengan asam sitrat dan asam tartarat menghasilkan warna yang kurang menarik. Hal ini menunjukkan kandungan klorofil yang terlalu sedikit. Sehingga pada penelitian ini penambahan bubuk ekstrak daun kacang tujuh jurai dilakukan pada penambahan diatas $5 \%$ dimulai dari penambahan $10 \%$, $15 \%, 20 \%, 25 \%$ dan $30 \%$.

Tujuan penelitian adalah mengetahui pengaruh penambahan bubuk ekstrak daun kacang tujuh jurai terhadap sifat fisik dan kimia tablet effervescent. Dari uraian diatas penulis telah melakukan penelitian dengan judul "Pembuatan minuman fungsional tablet effervescent dari bubuk ekstrak daun kacang tujuh jurai (Phaseolus lunatus, L.)".

\section{Metode}

Bahan baku utama yang digunakan dalam penelitian ini adalah daun kacang tujuh jurai dan jeruk nipis dari Desa Duku, Kecamatan Pauh, Sumatera Barat. Bahan pembuat tablet effervescent yaitu maltodekstrin, asam sitrat, asam tartarat, natrium bikarbonat, magnesium stearat (Brataco) dan sukrosa. Bahan untuk analisis kimia yang digunakan yaitu indikator kanji/pati $1 \%$, larutan iod $0,01 \mathrm{~N}$ (Merck), larutan buffer, phenolphetalin, metanol (pa), aseton (pa), DPPH (Sigma Aldrich), aquades, dan lain-lain.

Alat yang digunakan dalam pengolahan adalah pisau, timbangan, baskom, kain saring, blender, sendok aluminium. Alat pencetak tablet atau press sealer dibuat sederhana dengan bahan stainless steel serta alat-alat yang digunakan dalam analisis adalah gelas piala 500 $\mathrm{ml}$, labu ukur $100 \mathrm{ml}$, cawan aluminium, erlenmeyer 250 $\mathrm{ml}$, pipet tetes, gelas ukur $50 \mathrm{ml}$, neraca analitik (Kern ABJ 220-4M), desikator, oven (Philip Harris Ltd), spektrofotometer (Shimadzu UV-1800), pH meter (Delta OHM HD 2105.2, Italy), pipet tetes, stopwatch, kertas saring, wadah plastik, gelas, kapas, buret (VITLAB, Germany), jangka sorong (KENMASTER), Texture Analyzer (CT-3 Brookfield), Friabiliator roche, Hunter Lab Colorimeter (ColorFlex EZ), spray dryer (BUCHI B-290) dan lain-lain yang digunakan untuk analisis.

\subsection{Rancangan penelitian}

Penelitian ini menggunakan Rancangan Acak Lengkap (RAL) dengan perlakuan penambahan bubuk ekstrak daun kacang tujuh jurai dan 3 ulangan. Data yang diperoleh dianalisis secara statistik dengan uji $\mathrm{F}$ dan jika berbeda nyata dilanjutkan dengan uji Duncan's New Multiple Range Test (DNMRT) pada taraf nyata $5 \%$.

Berikut perlakuan penambahan bubuk ekstrak daun kacang tujuh jurai yang digunakan pada penelitian ini, yaitu : A (penambahan bubuk ekstrak daun kacang tujuh jurai 10\%), B (penambahan bubuk ekstrak daun kacang tujuh jurai 15\%), C (penambahan bubuk ekstrak daun kacang tujuh jurai 20\%), D (penambahan bubuk ekstrak daun kacang tujuh jurai 25\%), dan E (penambahan bubuk ekstrak daun kacang tujuh jurai 30\%). 
Tabel 1.

Formulasi pembuatan tablet effervescent bubuk ekstrak daun kacang tujuh jurai

\begin{tabular}{|c|c|c|c|c|c|}
\hline \multirow{2}{*}{ Bahan } & \multicolumn{5}{|c|}{ Perlakuan } \\
\hline & $\mathrm{A}$ & $\mathrm{B}$ & $\mathrm{C}$ & $\mathrm{D}$ & $\mathrm{E}$ \\
\hline Bubuk ekstrak daun kacang tujuh jurai (g) & 28,00 & 42,00 & 56,00 & 70,00 & 84,00 \\
\hline Asam sitrat $(\mathrm{g})$ & 48,86 & 48,86 & 48,86 & 48,86 & 48,86 \\
\hline Asam tartarat (g) & 48,86 & 48,86 & 48,86 & 48,86 & 48,86 \\
\hline Natrium bikarbonat (g) & 113,40 & 113,40 & 113,40 & 113,40 & 113,40 \\
\hline Magnesium stearat (g) & 2,80 & 2,80 & 2,80 & 2,80 & 2,80 \\
\hline Sukrosa (g) & 66,08 & 66,08 & 66,08 & 66,08 & 66,08 \\
\hline
\end{tabular}

Keterangan: Jumlah bubuk ekstrak daun kacang tujuh jurai yang diberikan berdasarkan persentase setiap perlakuan terhadap jumlah formulasi tablet effervescent yang meliputi (asam sitrat, asam tartarat, natrium bikarbonat, magnesium stearate dan sukrosa yang jumlah seluruhnya $280 \mathrm{~g}$ ) dengan berat pertablet $3,5 \mathrm{~g}$.

\subsection{Pelaksanaan penelitian}

\subsubsection{Pembuatan ekstrak daun kacang tujuh jurai modifikasi (Natalia, 2011)}

Daun kacang tujuh jurai disortasi dan dicuci bersih, kemudian dipotong kecil dengan ukuran $\pm 1 \mathrm{~cm}$. Ditimbang daun kacang tujuh jurai $3 \mathrm{~kg}$ dan air dengan perbandingan daun kacang tujuh jurai dan air yaitu 1:2 (b/v), kemudian diblender sampai halus. Selanjutnya dipisahkan antara ampas daun kacang tujuh jurai dengan ekstrak dengan menggunakan kain saring hingga diperoleh ekstrak daun kacang tujuh jurai.

\subsubsection{Pembuatan ekstrak sari buah jeruk nipis}

Buah jeruk nipis yang telah disortasi, dicuci, dibelah menjadi dua, diperas atau ditekan kemudian disaring dengan kain saring dan diambil sari buah jeruk nipisnya.

\subsubsection{Pembuatan bubuk ekstrak daun kacang tujuh jurai}

Proses pembuatan bubuk ekstrak daun kacang tujuh jurai yaitu $100 \mathrm{ml}$ ekstrak daun kacang tujuh jurai ditambah dengan $10 \%$ atau $10 \mathrm{ml}$ sari buah jeruk nipis, ditambah dengan maltodekstrin $15 \%(\mathrm{~b} / \mathrm{v})$ atau $15 \mathrm{~g}$ maltodekstrin dalam $100 \mathrm{ml}$ ekstrak daun kacang tujuh jurai, kemudian dihomogenkan dengan wadah yang tetutup. Lalu dikeringkan dengan menggunakan spray dryer pada suhu inlet $160^{\circ} \mathrm{C}$ suhu outlet $80^{\circ} \mathrm{C}$.

\subsubsection{Pembuatan tablet effervescent daun kacang tujuh jurai}

Pembuatan tablet effervescent dari ekstrak daun kacang tujuh jurai dengan metode kempa langsung Suhery et al. (2016). Bahan aktif yang digunakan adalah asam sitrat, asam tartarat dan natrium bikarbonat. Dilakukan penimbangan masing-masing bahan yaitu bubuk ekstrak daun kacang tujuh jurai, asam sitrat, asam tartarat, natrium bikarbonat, sukrosa dan magnesium stearat. Kemudian pencampuran bahan aktif, sukrosa dan magnesium stearat. Bahan aktif, sukrosa dan magnesium stearat yang telah homogen kemudian ditambah bubuk ekstrak daun kacang tujuh jurai. Pencampuran dilakukan dengan cepat, serbuk effervescent ditimbang 3,5 g dicetak dan dikemas.

\subsubsection{Pengamatan}

Pengamatan pada penelitian ini meliputi pengamatan ekstrak daun kacang tujuh jurai, sari jeruk nipis dan bubuk ekstrak daun kacang tujuh jurai : $\mathrm{pH}$ (AOAC, 2006), vitamin C (AOAC, 2006), aktivitas antioksidan (Huang et al., 2006), kadar klorofil (Groos, 1991), dan kadar air (AOAC, 2006). Pengamatan fisik tablet effervescent : ketebalan dan diameter (Ben, 2008), waktu larut (Nariswara et al., 2013), kekerasan (Texture Analyser), kerapuhan (Ben, 2008). Analisis kimia tablet effervescent : Kadar air (AOAC, 2006), pH (AOAC, 2006), vitamin C (AOAC, 2006), aktivitas antioksidan (Huang et al., 2006), kadar klorofil (Groos, 1991), dan pengukuran warna (Andarwulan et al., 2011).

\section{Hasil dan pembahasan}

\subsection{Pengamatan ekstrak daun kacang tujuh jurai, sari jeruk nipis dan bubuk ekstrak daun kacang tujuh jurai}

Ekstrak daun kacang tujuh jurai, sari jeruk nipis dan bubuk ekstrak daun kacang tujuh jurai dilakukan analisis yaitu $\mathrm{pH}$, vitamin $\mathrm{C}$, aktivitas antioksidan, kadar klorofil dan kadar air. Hasil analisis dapat dilihat pada Tabel 2.

Tabel 2.

Hasil analisis ekstrak daun kacang tujuh jurai, sari jeruk nipis dan bubuk ekstrak daun kacang tujuh jurai

\begin{tabular}{llll}
\hline \multirow{2}{*}{ Analisis } & Hasil Analisis & \\
\cline { 2 - 3 } & $\begin{array}{l}\text { Ekstrak daun kacang } \\
\text { tujuh jurai }\end{array}$ & Sari jeruk nipis & $\begin{array}{l}\text { Bubuk ekstrak daun } \\
\text { kacang tujuh jurai }\end{array}$ \\
\hline $\mathrm{pH}$ & 4,6 & 2,4 & 4,6 \\
Vitamin C & $3,64 \mathrm{mg} / 100 \mathrm{~g}$ bahan & $1,06 \mathrm{mg} / 100 \mathrm{~g}$ bahan & $5,38 \mathrm{mg} / 100 \mathrm{~g} \mathrm{bahan}$ \\
Aktivitas Antioksidan & $24,65 \%$ & $31,25 \%$ & $23,85 \%$ \\
Kadar Klorofil & $41,14 \mathrm{mg} / \mathrm{g}$ & - & $35,93 \mathrm{mg} / \mathrm{g}$ \\
Kadar Air & - & - & $6,64 \%$ \\
\hline
\end{tabular}


Analisis terhadap ekstrak daun kacang tujuh jurai, sari jeruk nipis dan bubuk ekstrak daun kacang tujuh jurai dilakukan untuk mengetahui pengaruh pengeringan spray dryer terhadap komponen bahan aktif. Penentuan analisis bubuk ekstrak daun kacang tujuh jurai berasal dari penambahan $10 \%$ sari jeruk nipis dan $15 \%$ maltodektrin dalam $1000 \mathrm{ml}$ ekstrak daun kacang tujuh jurai dengan perolehan rendemen 20,09\%. Rendahnya rendemen diduga pengikatan klorofil terhadap bahan pengisi yang rendah karena pengaruh penggunaan pelarut air dalam proses ekstraksi. Klorofil memiliki tingkat kepolaran yang rendah. Oleh karena itu, tingkat kepolaran pelarut yang digunakan untuk ekstraksi akan mempengaruhi banyaknya klorofil yang terekstrak (Fitri et al., 2012). Selain itu juga disebabkan terdapat bubuk yang menempel pada dinding tabung spray dryer.

Dari hasil analisis dapat dilihat pada Tabel 2 bahwa pH pada ekstrak daun kacang tujuh jurai yaitu 4,6, sari jeruk nipis 2,4 dan bubuk ekstrak daun kacang tujuh jurai 4,6. Nilai $\mathrm{pH}$ yang diperoleh menunjukkan sifat asam pada bahan.

Hasil analisis vitamin $\mathrm{C}$ pada ekstrak daun kacang tujuh jurai yang diperoleh yaitu $3,64 \mathrm{mg} / 100 \mathrm{~g}$ bahan, jeruk nipis yang diperoleh yaitu 1,06 mg/100 g bahan dan bubuk ekstrak daun kacang tujuh jurai yang diperoleh yaitu 5,38 mg/100 $\mathrm{g}$ bahan.

Tabel 3.

Hasil pengamatan fisik tablet effervescent

\begin{tabular}{llll}
\hline Perlakuan & Ketebalan $(\mathrm{cm})$ & Waktu Larut (Detik) & Kerapuhan $(\%)$ \\
\hline A & $0,749 \pm 0,05 \mathrm{~b}$ & $53,76 \pm 0,57 \mathrm{a}$ & $0,13 \pm 0,04 \mathrm{a}$ \\
$\mathrm{B}$ & $0,738 \pm 0,05 \mathrm{a}$ & $65,73 \pm 0,32 \mathrm{ab}$ & $0,55 \pm 0,03 \mathrm{~b}$ \\
$\mathrm{C}$ & $0,742 \pm 0,02 \mathrm{a}$ & $81,30 \pm 0,01 \mathrm{bc}$ & $0,66 \pm 0,06 \mathrm{~b}$ \\
$\mathrm{D}$ & $0,743 \pm 0,04 \mathrm{a}$ & $96,57 \pm 0,57 \mathrm{~cd}$ & $0,83 \pm 0,09 \mathrm{~b}$ \\
E & $0,750 \pm 0,03 \mathrm{~b}$ & $106,38 \pm 0,52 \mathrm{~d}$ & $1,25 \pm 0,04 \mathrm{c}$ \\
\hline KK $(\%)$ & $0,3 \%$ & $8,88 \%$ & $20,05 \%$ \\
\hline
\end{tabular}

Keterangan: Angka-angka pada lajur yang sama diikuti huruf kecil yang tidak sama berbeda nyata menurut DNMRT pada taraf nyata $5 \%$

\subsubsection{Ketebalan dan diameter tablet}

Hasil sidik ragam tablet effervescent berpengaruh nyata $(\mathrm{P}<0,05)$ terhadap ketebalan tablet effervescent. Hasil Anova dan uji DNMRT penampakan tablet effervescent dapat dilihat pada Tabel 3. Menurut Departemen Kesehatan Republik Indonesia (2014), bahwa diameter tablet tidak boleh melebihi tiga kali tebal tablet dan tidak kurang dari sepertiga kali tebal tablet. Pengujian ketebalan dan diameter berkaitan dengan penampilan yang menarik sebagai hasil perkiraan berat tablet sesuai dengan jumlah bahan yang dicetak.

Hasil pengamatan terhadap diameter tablet effervescent yaitu 2,24 cm. Hasil Pada Tabel 3 dapat dilihat bahwa tebal tablet effervescent yang diperoleh berkisar antara $0,738 \mathrm{~cm}-0,750 \mathrm{~cm}$. Ketebalan tablet effervescent tertinggi terdapat pada perlakuan E yaitu $0,750 \mathrm{~cm}$ sedangkan ketebalan terendah terdapat pada perlakuan B yaitu $0,738 \mathrm{~cm}$. Pada Tabel 3 terlihat bahwa ketebalan tablet effervescent pada perlakuan A dan E menunjukkan pengaruh yang tidak berbeda nyata namun berpengaruh nyata terhadap perlakuan B, C dan D. Dari keseluruhan ketebalan tablet secara umum ketebalan tablet sudah memenuhi standar ketetapan tablet.
Hasil analisis aktivitas antioksidan dilakukan pada konsentrasi 3.000 ppm, ekstrak bubuk daun kacang tujuh jurai yang diperoleh yaitu $24,65 \%$, jeruk nipis yang diperoleh yaitu 31,25\% dan bubuk ekstrak daun kacang tujuh jurai yang diperoleh yaitu 23,85\%.

Hasil analisis kadar klorofil ekstrak daun kacang tujuh jurai yang diperoleh yaitu $41,14 \mathrm{mg} / \mathrm{g}$ dan bubuk ekstrak daun kacang tujuh jurai yang diperoleh yaitu $35,93 \mathrm{mg} / \mathrm{g}$. Kadar klorofil mengalami penurunan diduga penggunaan suhu tinggi pada pengeringan dengan spray dryer. Sesuai dengan pendapat (Azizah, 2014) bahwa terjadi penurunan kadar klorofil ekstrak daun pegagan dari 43,58 mg/g menjadi $31,11 \mathrm{mg} / \mathrm{g}$ setelah dikeringkan dengan spray dryer karena pengaruh penggunaan suhu tinggi. Hal ini diduga disebabkan karena pada suhu tinggi terjadi degradasi klorofil (Groos, 1991). Hasil analisis kadar air pada bubuk ekstrak daun kacang tujuh jurai yaitu $6,64 \%$.

\subsection{Pengamatan fisik tablet effervescent}

Hasil pengamatan fisik tablet effervescent dari bubuk ekstrak kacang tujuh jurai: ketebalan, waktu larut, dan kerapuhan dapat dilihat pada Tabel 3.
Berdasarkan data ketebalan tablet effervescent, penambahan bubuk yang berbeda-beda mempengaruhi ketebalan tablet saat perlakuan cetakan. Tablet effervescent yang dicetak menghasilkan diameter yang sama karena ukuran diameter pencetak yang sama. Salah satu penyebab perbedaan ketebalan tablet menurut Rori et al., (2016) bahwa ketebalan tablet dapat dipengaruhi oleh tekanan yang digunakan saat pencetakan tidak sama. Hal ini karena cetakan yang digunakan untuk membuat tablet dibuat sederhana dengan prinsip ulir, tekanan yang digunakan pada saat pengempaan tablet dengan ditahan selama 30 detik.

\subsubsection{Waktu larut}

Hasil analisis sidik ragam penambahan bubuk ekstrak daun kacang tujuh jurai berpengaruh nyata $(\mathrm{P}<0,05)$ terhadap waktu larut tablet effervescent. Waktu larut tablet effervescent merupakan parameter yang paling penting karena dalam sistem effervescent hal yang utama adalah efek visual pada saat peleburan dan munculnya proses karbonasi tablet di dalam larutan (Ansar, 2011).

Waktu larut merupakan lamanya tablet untuk larut sempurna dalam suatu ukuran saji dalam volume air 
tertentu. Kelarutan pada tablet effervescent disebabkan karena reaksi antara asam dan karbonat dengan air. Pada Tabel 3 dapat dilihat bahwa waktu larut tablet effevervescent berkisar antara 53,76 detik - 106,38 detik. Waktu larut tercepat pada perlakuan A (Penambahan bubuk ekstrak daun kacang tujuh jurai 10\%) yaitu 53,76 detik dan waktu larut terlambat terdapat pada perlakuan E (Penambahan bubuk ekstrak daun kacang tujuh jurai $30 \%$ ) yaitu 106,38 detik. Berdasarkan Departemen Kesehatan Republik Indonesia (2014), waktu larut tablet effervescent berkisar antara 60-120 detik. Pada produk tablet effervescent bubuk ekstrak daun kacang tujuh jurai pada semua perlakuan menunjukkan bahwa waktu larut hasil penelitian memenuhi semua persyaratan waktu larut tablet effervescent yaitu berada dibawah dan diantara waktu larut standar.

Semakin banyak penambahan bubuk ekstrak daun kacang tujuh jurai, maka waktu larut tablet effervescent akan semakin lama. Hal ini kemungkinan disebabkan asam sitrat dan asam tartarat yang semakin sulit untuk mengikat bubuk ekstrak daun kacang tujuh jurai sehingga menyebabkan melambatnya reaksi antara asam dan karbonat.

Pada penelitian Syukri et al. (2018) dalam pembuatan tablet effervescent dari buah mahkota dewa didapatkan waktu larut tablet effervescent 1 sebesar 255 detik, tablet effervescent 2 sebesar 341,4 detik dan tablet effervescent 3 sebesar 233 detik. Jika dibandingkan dengan waktu larut tablet Redoxon sebagai pembanding yaitu 77 detik. Waktu larut tablet effervescent pada perlakuan A (Penambahan bubuk ekstrak daun kacang tujuh jurai $10 \%$ ) dan B (Penambahan bubuk ekstrak daun kacang tujuh jurai $15 \%$ ) lebih cepat dibandingkan dengan waktu larut tablet Redoxon, sedangkan jika dibandingkan pada perlakuan $\mathrm{C}$ (Penambahan bubuk ekstrak daun kacang tujuh jurai 20\%), D (Penambahan bubuk ekstrak daun kacang tujuh jurai 25\%) dan E (Penambahan bubuk ekstrak daun kacang tujuh jurai 30\%) waktu larut tablet effervescent lebih lama dibandingkan dengan tablet Redoxon.

Lamanya waktu larut juga dapat disebabkan oleh terjadinya reaksi karbonasi saat pencampuran bahan asam dan bahan basa sebelum pencetakan sehingga menyebabkan daya effervescent berkurang. Selain itu, kelembaban udara ruangan ketika pengujian juga akan menyebabkan menurunnya kualitas tablet sehingga daya larutnya semakin lama. Menurut Syukri et al. (2018) kekerasan tablet effervescent juga berpengaruh terhadap waktu larut, semakin lunak tablet yang dihasilkan karena pengaruh lingkungan maka akan semakin lama daya larutnya.

\subsubsection{Kekerasan}

Pengujian kekerasan merupakan pengukuran sifat mekanik tablet yang merupakan persyaratan tidak mutlak. Menurut Ben (2008) pengujian kekerasan diperlukan untuk mengontrol pengemasan pada saat pengendalian pengangkutan tablet. Uji kekerasan dengan menggunakan Texture Analyzer terhadap tablet effervescent bubuk ekstrak daun kacang tujuh jurai pada semua perlakuan menghasilkan kekerasan antara 181,85 - 274,64 N/cm².
Kekerasan tablet mencermikan kekuatan tablet secara keseluruhan (Hadisoewigynyo dan Fudholi, 2013). Kekerasan ini dipakai sebagai ukuran dari tekanan pengempaan. Semakin besar tekanan yang diberikan saat pencetakan akan meningkatkan kekerasan tablet. Pada umumnya tablet yang keras memiliki waktu hancur yang lama (lebih sukar hancur) dan disolusi yang rendah, namun tidak selamanya demikian (Syamsia et al., 2017). Menurut Nariswara et al. (2013) salah satu faktor yang dapat mempengaruhi nilai kekerasan tablet adalah jumlah bahan pengisi, faktor higroskopisitas atau kemampuan suatu zat untuk menyerap molekul air dari lingkungan, jumlah dan jenis bahan pengikat yang digunakan. Setelah proses pencetakan, tablet effervescent disimpan dan dikelompokkan pada setiap ulangannya. Pada saat penyimpanan tersebut tablet mengalami proses higroskopis dengan tingkat yang berbeda hal ini yang memungkinkan terjadinya perbedaan nilai kekerasan tablet effervescent.

Selain itu dipengaruhi oleh penggunaan bahan pengikat yaitu sukrosa yang berfungsi mengikat komponen-komponen tablet effervescent. Menurut (Pratiwi dan Hertiana, 2013) sukrosa memiliki karakteristik partikel dan sifat fisik tablet yang baik. Maka, semakin sedikit penambahan bubuk ekstrak daun kacang tujuh jurai sukrosa akan lebih mudah untuk mengikat komponen tablet agar lebih keras, sedangkan jika semakin banyak penambahan bubuk ekstrak daun kacang tujuh jurai maka sukrosa akan semakin sulit untuk membentuk tablet yang lebih keras dan kompak.

\subsubsection{Kerapuhan}

Hasil analisis sidik ragam tablet effervescent berpengaruh nyata $(\mathrm{P}<0,05)$ terhadap kerapuhan tablet effervescent. Prinsip dari pengujian kerapuhan adalah perhitungan massa seluruh partikel tablet yang berjatuhan oleh pengujian mekanik dengan menggunakan alat Friabilator Roche yang berputar melewati plat lengkung, kemudian tablet akan jatuh dan bergulir kembali pada putaran berikutnya, tablet akan berputar pada kecepatan $20 \mathrm{rpm}$ selama 4 menit. Kerapuhan dinyatakan dalam persen yang ditentukan dari massa sebelum pengujian tablet (Ben, 2008). Uji kerapuhan bertujuan untuk mengetahui kemampuan tablet untuk menahan guncangan tanpa runtuh selama manufaktur, pengemasan, pengiriman dan penggunaan kepada konsumen. Menurut Syukri et al. (2018) tablet yang baik mempunyai nilai standar kerapuhan tidak lebih dari $1 \%$. Penggunaan bahan pengikat juga berpengaruh terhadap kerapuhan tablet, tablet yang tebal dan padat umumnya lebih kuat, namun tablet yang tipis akan mudah rapuh.

Pada Tabel 3 dapat dilihat bahwa kerapuhan tablet effervescent berkisar antara 0,13\% - 1,25\%. Kerapuhan tablet effervescent pada perlakuan A, B, C dan D memenuhi standar kerapuhan. Sedangkan perlakuan E melebihi standar kerapuhan. Kerapuhan tertinggi terdapat pada perlakuan E (Penambahan bubuk ekstrak daun kacang tujuh jurai 30\%) yaitu $1,25 \%$ dan kerapuhan tablet effervescent terendah terdapat pada perlakuan A (Penambahan bubuk ekstrak daun kacang tujuh jurai $10 \%$ ) yaitu $0,13 \%$. Sedangkan jika 
dibandingkan dengan kerapuhan tablet Redoxon yang peguji lakukan sendiri yaitu $2,73 \%$, hal ini menunjukkan kerapuhan tablet Redoxon lebih tinggi dibandingkan perlakuan penambahan bubuk ekstrak daun kacang tujuh jurai. Selain itu karena semakin banyak penambahan bubuk ekstrak daun kacang tujuh jurai menyebabkan semakin tinggi tingkat kerapuhan tablet effervescent.

Semakin banyak penambahan bubuk ekstrak daun kacang tujuh jurai maka persentase kerapuhan tablet effervescent akan semakin besar, artinya tablet semakin mudah pecah atau sumbing. Kerapuhan juga dapat dipengaruhi oleh penggunaan bahan pengikat yaitu sukrosa yang berfungsi mengikat komponen-komponen tablet effervescent. Menurut Lieberman et al. (1989) bahwa bahan pengikat berguna untuk mengikat komponen-komponen penyusun tablet agar dihasilkan tekstur yang kompak dan tidak pecah ketika dikempa.
Semakin sedikit penambahan bubuk ekstrak daun kacang tujuh jurai maka sukrosa akan lebih mudah untuk mengikat komponen tablet agar lebih kompak sehingga tablet tidak mudah rapuh, sedangkan jika semakin banyak penambahan bubuk ekstrak daun kacang tujuh jurai maka sukrosa akan semakin sulit untuk membentuk tablet yang lebih keras dan kompak, sehingga tablet akan mudah rapuh. Selain itu kadar air dari sukrosa juga berfungsi sebagai pengikat tablet yang membuat meningkatnya interaksi antara partikel yang berkorelasi secara langsung kuatnya ikatan partikel tablet (Syukri et al., 2018).

\subsection{Analisis kimia tablet effervescent}

Hasil analisis kimia tablet effervescent dari bubuk ekstrak kacang tujuh jurai dapat dilihat pada Tabel 4.

Tabel 4.

Hasil analisis kimia tablet effervescent

\begin{tabular}{|c|c|c|c|c|c|c|}
\hline Perlakuan & Kadar Air (\%) & $\mathrm{pH}$ & $\begin{array}{l}\text { Vitamin } C \\
\text { (mg/100 g bahan) }\end{array}$ & $\begin{array}{l}\text { Antioksidan } \\
(\%)\end{array}$ & $\begin{array}{l}\text { Kadar Klorofil } \\
(\mathrm{mg} / \mathrm{g})\end{array}$ & Warna $\left({ }^{\circ} \mathrm{Hue}\right)$ \\
\hline $\mathrm{A}$ & $2,28 \pm 0,33 \mathrm{a}$ & $5,5 \pm 0,05$ & $0,48 \pm 0,01 \mathrm{a}$ & $15,21 \pm 0,53 \mathrm{a}$ & $3,56 \pm 0,45 a$ & $60,03 \pm 1,32 b$ \\
\hline $\mathrm{B}$ & $5,66 \pm 0,20 \quad b$ & $5,4 \pm 0,05$ & $0,54 \pm 0,04 \mathrm{a}$ & $17,20 \pm 0,62 \mathrm{a}$ & $4,84 \pm 0,29 b$ & $57,52 \pm 0,37 \mathrm{a}$ \\
\hline $\mathrm{C}$ & $6,06 \pm 0,15 \quad b$ & $5,4 \pm 0,05$ & $0,61 \pm 0,01 \quad b$ & $18,62 \pm 0,31 \mathrm{a}$ & $6,14 \pm 0,22 \mathrm{c}$ & $56,86 \pm 0,51 \mathrm{a}$ \\
\hline $\mathrm{D}$ & $7,81 \pm 0,58 \quad b c$ & $5,4 \pm 0,05$ & $0,69 \pm 0,05$ & $22,10 \pm 0,24 a b$ & $7,22 \pm 0,41$ & $56,47 \pm 0,62 \mathrm{a}$ \\
\hline $\mathrm{E}$ & $8,94 \pm 0,69 \quad c$ & $5,5 \pm 0,05$ & $0,80 \pm 0,04$ & $26,45 \pm 0,47 \quad b$ & $7,81 \pm 0,57 \mathrm{~d}$ & $56,45 \pm 0,62 \mathrm{a}$ \\
\hline $\mathrm{KK}(\%)$ & 14,69 & 1,9 & 4,11 & 12,35 & 4,62 & 0,89 \\
\hline
\end{tabular}

Keterangan: Angka-angka pada lajur yang sama diikuti huruf kecil yang tidak sama berbeda nyata menurut DNMRT pada taraf nyata $5 \%$

\subsubsection{Kadar air}

Hasil analisis sidik ragam penambahan bubuk ekstrak daun kacang tujuh jurai berpengaruh nyata $(\mathrm{P}<0,05)$ terhadap kadar air tablet effervescent. Hasil Anova dan uji DNMRT kadar air tablet effervescent dapat dilihat pada Tabel 4. Kadar air tablet effervescent yang diperoleh berkisar antara 2,28\% - 8,94\%. Kadar air tertinggi terdapat pada perlakuan $\mathrm{E}$ yaitu $8,94 \%$ dan kadar air terendah terdapat pada perlakuan A yaitu $2,28 \%$. Semakin banyak penambahan bubuk ekstrak daun kacang tujuh jurai maka semakin tinggi kadar airnya. Semakin sedikit penambahan bubuk ekstrak daun kacang tujuh jurai semakin rendah kadar airnya.

Pada bubuk ekstrak daun kacang tujuh jurai mengandung kadar air sekitar 6,64\%, sedangkan pada perlakuan A kadar air lebih rendah. Hal ini disebabkan karena sifat bahan asam sitrat, asam tartarat, natrium bikarbonat dan sukrosa yang digunakan untuk membuat tablet effervescent bersifat higroskopis. Menurut Zulfri et al. (2012) bahan higroskopis pada produk akan selalu memiliki kadar air sisa. Kandungan air dalam bahan higroskopis merupakan kelembaban terikat (tetap) di dalam bahan, karena ditutup kapiler, uap air terikat di dalam bahan, dan adanya tegangan permukaan air.

\subsection{2. pH larutan}

Hasil analisis sidik ragam penambahan bubuk ekstrak daun kacang tujuh jurai berpengaruh tidak nyata $(\mathrm{P}<$ $0,05)$ terhadap $\mathrm{pH}$ minuman effervescent. Pada Tabel 4. menunjukkan $\mathrm{pH}$ tablet effervescent yang diperoleh berkisar antara 5,4-5,5. Jika dibandingkan dengan $\mathrm{pH}$ tablet Redoxon yang peneliti lakukan sebagai pembanding diperoleh 5,52. Hal ini menunjukkan bahwa $\mathrm{pH}$ tablet effervescent pada perlakuan penambahan bubuk ekstrak daun kacang tujuh jurai masih berkisaran pada $\mathrm{pH}$ tablet Redoxon.

Penambahan bubuk ekstrak daun kacang tujuh jurai tidak memberikan pengaruh terhadap $\mathrm{pH}$ tablet effervescent yang dihasilkan, karena nilai $\mathrm{pH}$ tablet effervescent masih dikategorikan $\mathrm{pH}$ asam. Selain itu, $\mathrm{pH}$ tidak mengalami penurunan karena penambahan jumlah asam sama pada setiap perlakuan.

Pada penelitian Aslani dan Hajar (2013) bahwa pH efferverscent berada pada kisaran 5,5 - 6,2. Salah satu faktor yang dapat mempengaruhi keasaman $\mathrm{pH}$ adalah pembentukan $\mathrm{CO}_{2}$ pada saat terjadi reaksi effervescing dalam air yang sebagian akan larut membentuk asam karbonat. Asam karbonat ini kemudian mengurai menghasilkan ion $\mathrm{H}+$ dalam larutan yang menyebabkan keasaman pada larutan (Sandrasari dan Abidin, 2011).

\subsubsection{Vitamin C}

Hasil analisis sidik ragam penambahan bubuk ekstrak daun kacang tujuh jurai berpengaruh nyata $(\mathrm{P}<0,05)$ terhadap vitamin $\mathrm{C}$ tablet effervescent. Kadar vitamin $\mathrm{C}$ tablet effervescent yang diperoleh berkisar antara 0,48 $\mathrm{mg} / 100 \mathrm{~g}$ bahan - 0,80 mg/100 g bahan. Kadar vitamin C tertinggi terdapat pada perlakuan E (Penambahan bubuk ekstrak daun kacang tujuh jurai $30 \%$ ) yaitu $0,80 \mathrm{mg} / 100$ $\mathrm{g}$ bahan dan kadar vitamin $\mathrm{C}$ terendah terdapat pada 
perlakuan A (Penambahan bubuk ekstrak daun kacang tujuh jurai $10 \%$ ) yaitu $0,48 \mathrm{mg} / 100 \mathrm{~g}$ bahan.

Kadar vitamin $\mathrm{C}$ meningkat seiring dengan peningkatan penambahan bubuk ekstrak daun kacang tujuh jurai. Hal ini disebabkan karena dalam proses pembuatan bubuk ekstrak daun kacang tujuh jurai dilakukan penambahan sari jeruk nipis sebagai sumber vitamin C sebanyak $10 \%$ dari ekstrak daun kacang tujuh jurai.

Hasil analisis kadar vitamin C tablet effervescent lebih rendah dibandingkan bubuk ekstrak daun kacang tujuh jurai yaitu 5,38 mg/100 g bahan, dan sari jeruk nipis yaitu $1,06 \mathrm{mg} / 100 \mathrm{~g}$ bahan. Vitamin $\mathrm{C}$ mudah rusak selama pengolahan, menurut Febrianti et al. (2012), dengan adanya asam sitrat dalam tablet effervescent menyebabkan peningkatan kandungan air pada tablet yang dapat merusak stabilitas vitamin C. Vitamin C dikenal memiliki sifat yang mudah larut dalam air dan mudah rusak dengan pemanasan yang lama. Selain itu, menurut Hasanah, (2018) vitamin C mudah teroksidasi dan proses tersebut dipercepat oleh panas, sinar, alkali, enzim, oksidator serta katalis tembaga dan besi. Maka kemungkinan penurunan vitamin $\mathrm{C}$ disebabkan mudah mengalami kerusakan akibat adanya sinar, terjadi oksidasi oleh oksigen saat melakukan penimbangan sampai pencetakan tablet.

\subsubsection{Aktivitas antioksidan}

Hasil analisis sidik ragam penambahan bubuk ekstrak daun kacang tujuh jurai berpengaruh nyata $(\mathrm{P}<0,05)$ terhadap aktivitas antioksidan tablet effervescent. Analisis aktivitas antioksidan dilakukan pada konsentrasi 10.000 ppm. Aktivitas antioksidan yang diperoleh berkisar antara 15,21\% - 26,45\%. Persen inhibisi DPPH tablet effervescent dapat dinyatakan dengan konsentrasi senyawa uji yang menyebabkan penangkapan terhadap radikal bebas konsentrasi 0,5 g/10 ml. Aktivitas antioksidan tertinggi terdapat pada perlakuan $\mathrm{E}$ (Penambahan bubuk ekstrak daun kacang tujuh jurai $30 \%$ ) yaitu $26,45 \%$ dan aktivitas antioksidan terendah terdapat pada perlakuan A (Penambahan bubuk ekstrak daun kacang tujuh jurai $10 \%$ ) yaitu $15,21 \%$. Semakin banyak penambahan ekstrak bubuk daun kacang tujuh jurai maka aktivitas antioksidannya semakin meningkat. Hal ini disebabkan karena adanya pengaruh klorofil dan vitamin $\mathrm{C}$ yang berasal dari ekstrak daun kacang tujuh jurai dan sari jeruk nipis. Menurut Nazwa dan Azrina (2017), jeruk nipis mengandung vitamin C sebanyak $27,78 \mathrm{mg} / 100 \mathrm{~g}$ jeruk sebagai sumber antioksidan. Selain itu kandungan antioksidan yang terdapat pada daun kacang tujuh jurai yaitu berasal dari senyawa flavonoida dan alkaloid.

Hasil aktivitas antioksidan tablet effervescent dari semua perlakuan tersebut dibandingkan dengan aktivitas antioksidan pada ekstrak daun kacang tujuh jurai dan bubuk ekstrak daun kacang tujuh jurai didapatkan aktivitas antioksidan yang lebih kecil dalam tablet effervescent. Aktivitas antioksidan pada ekstrak daun kacang tujuh jurai yaitu 24,65\% dan bubuk ekstrak daun kacang tujuh jurai yaitu $23,85 \%$ pada konsentrasi $30.000 \mathrm{ppm}$. Hal ini disebabkan karena selama proses pembuatan tablet effervescent mulai dari pembuatan bahan utama tablet hingga proses pencampuran, senyawa antioksidan mengalami penurunan akibat teroksidasi oleh oksigen dan cahaya. Selain itu dapat disebabkan karena penggunaan suhu tinggi, proses pembuatan bubuk menggunakan spray dryer untuk menghasilkan bubuk ekstrak daun kacang tujuh jurai menggunakan suhu inlet $160^{\circ} \mathrm{C}$ dan suhu outlet $80^{\circ} \mathrm{C}$. Sebagaimana disebutkan (Husni et al., 2014) bahwa kadar antioksidan menurun seiring dengan meningkatnya suhu dan lama waktu pemanasan.

\subsubsection{Kadar klorofil}

Hasil analisis sidik ragam penambahan bubuk ekstrak daun kacang tujuh jurai berpengaruh nyata $(\mathrm{P}<0,0,5)$ terhadap kadar klorofil tablet effervescent. Analisis kadar klorofil menggunakan metode spektrofotometer UV, dan mengukur nilai absorbansi larutan klorofil pada dua panjang gelombang yaitu $663 \mathrm{~nm}$ untuk pengukuran nilai absorbansi klorofil a dan $645 \mathrm{~nm}$ untuk pengukuran nilai absorbansi klorofil b. Kadar klorofil yang diperoleh berkisar antara 3,56 mg/g - 7,81 mg/g. Kadar klorofil tertinggi terdapat pada perlakuan E (Penambahan bubuk ekstrak daun kacang tujuh jurai $30 \%$ ) yaitu $7,81 \mathrm{mg} / \mathrm{g}$ dan kadar klorofil terendah terdapat pada perlakuan A (Penambahan bubuk ekstrak daun kacang tujuh jurai $10 \%$ ) yaitu $3,56 \mathrm{mg} / \mathrm{g}$.

Kadar klorofil meningkat seiiring peningkatan penambahan bubuk ekstrak daun kacang tujuh jurai. Semakin banyak penambahan bubuk ekstrak daun kacang tujuh jurai maka semakin tinggi kadar klorofilnya. Pada ekstrak daun kacang tujuh jurai diperoleh kadar klorofil 41,14 mg/g dan pada bubuk ekstrak daun kacang tujuh jurai diperoleh 35,93 mg/g, hasil ini menunjukkan pada produk terjadi penurunan kadar klorofil.

Selama pembuatan bubuk ekstrak daun kacang tujuh jurai dengan spray dryer digunakan suhu tinggi dengan waktu pengeringan yang cepat, hal ini juga mempengaruhi keberadaan klorofil dalam bubuk. Perlakuan panas akan menyebabkan klorofil dirubah menjadi pheophytin dengan substitusi magnesium oleh hidrogen pada saat pemanasan sehingga total klorofil ekstrak daun kacang tujuh jurai menurun. Hal ini didukung oleh Rohmat et al. (2014) bahwa dengan adanya pemanasan akan memberikan pengaruh kerusakan klorofil dengan membentuk pheophytin yang berwarna hijau pucat hingga berubah menjadi warna kecoklatan.

Pemberian asam pada tablet effervescent juga mempengaruhi klorofil pada bubuk, menurut Zheng et al. (2014) degradasi klorofil pada jaringan daun dipengaruhi oleh $\mathrm{pH}$. Pada media basa ( $\mathrm{pH}$ 9) klorofil sangat stabil terhadap panas, sedangkan pada media asam ( $\mathrm{pH}$ 3) tidak stabil. Warna klorofil akan segera memudar setelah pemanasan, hal ini dikarenakan penurunan nilai $\mathrm{pH}$ yang terjadi ketika pemanasan mengakibatkan pelepasan asam.

\subsubsection{Pengukuran warna}

Hasil analisis sidik ragam pengukuran warna tablet effervescent secara kuantitatif dengan penambahan 
bubuk ekstrak daun kacang tujuh jurai berpengaruh nyata $(\mathrm{P}<0,0,5)$ terhadap warna tablet effervescent. Warna yang diperoleh berkisar antara $56,45^{\circ} \mathrm{Hue}-$ $60,03^{\circ}$ Hue. Warna tertinggi terdapat pada perlakuan A (Penambahan bubuk ekstrak daun kacang tujuh jurai $10 \%$ ) yaitu $60,03^{\circ} \mathrm{Hue}$ menunjukkan semakin cerah warna tablet effervescent dan warna terendah terdapat pada perlakuan E (Penambahan bubuk ekstrak daun kacang tujuh jurai $30 \%$ ) yaitu $56,45^{\circ}$ Hue menunjukkan semakin gelap warna tablet effervescent.

Semakin sedikit penambahan bubuk ekstrak daun kacang tujuh jurai semakin putih. Sebaliknya semakin banyak penambahan bubuk ekstrak daun kacang tujuh jurai maka warna semakin hijau. Zat warna dari tablet yang besar dari daun kacang tujuh jurai merupakan warna alami, sehingga selama pengolahan warna tidak stabil. Menurut Andriyani et al. (2017) bahwa intensitas warna pigmen yang menurun dapat dikaitkan dengan suhu dan lama penyimpanan terhadap perlakuan sampel.

\section{Kesimpulan}

Perlakuan penambahan bubuk ekstrak daun kacang tujuh jurai yang berbeda-beda pada pembuatan minuman fungsional tablet effervescent berpengaruh nyata terhadap ketebalan, waktu larut, kerapuhan, kadar air, vitamin C, aktivitas antioksidan, kadar klorofil dan warna. Penambahan bubuk ekstrak daun kacang tujuh jurai tidak berpengaruh nyata terhadap diameter tablet, $\mathrm{pH}$ dan kekerasan tablet. Perlakuan terbaik tablet effervescent berdasarkan standar tablet effervescent dan sifat kimia adalah perlakuan E dengan ketebalan 0,750 $\mathrm{cm}$, waktu larut 106,38 detik, kerapuhan 1,25\%, kadar air $8,94 \%$, pH 5,5, vitamin C $0,80 \mathrm{mg} / 100 \mathrm{~g}$ bahan, aktivitas antioksidan 26,45\%, kadar klorofil 7,81 mg/g dan warna $56,45^{\circ} \mathrm{Hue}$.

\section{Daftar pustaka}

Alsuhaibani, A.M., ALkehayez, N.M., And, A.H.A., AlFaris, N.A., 2017. Effects of chlorophyll onb ody functioning and blood glucose levels. Asian J. Clin. Nutr. Vol. 9, No, 64-70. https://doi.org/DOI: 10.3923/ajen.2017.64.70

Andarwulan, N., Kusnandar, F., Herawati, D., 2011. Analisis Pangan. Dian Rakyat, Jakarta.

Andriyani, M.D., Dewi, E.N., Susanto, E., 2017. Stabilitas ekstrak pigmen lamun laut (Enhalus acoroides) dari perairan teluk awur jepara terhadap suhu dan lama penyimpanan. Pros. Semin. Nas. Has. -Hasil Penelit. Perikan. dan Kelaut. ke -VI Fak. Perikan. dan Ilmu Kelaut. - Pus. Kaji. Mitigasi Bencana dan Rehabil. Pesisir,Undip 384-400.

Ansar, 2011. Optimasi formula dan gaya tekan terhadap tekstur dan kelarutan tablet effervescent buah markisa. J. Teknol. Pertan. 12(2), 109-114.

AOAC, 2006. AOAC International Final Report and Executive Summaries From The AOAC International Presidential Task Force on Best Practices in Microbiological Methodology Contract Deliverable Due to The U. S . Food and Drug Administration Presidential Task Force on.

Aslani, A. dan, Jahangiri, H., 2013. Formulation, characterization and physicochemical evaluation of ranitidine effervescent tablets. Adv. Pharm. Bull. 3(2), 315-322.

Azizah, 2014. Pengaruh penambahan effervescent mix yang digunakan dalam pembuatan serbuk effervescent dari daun pegagan (Centella asiatica, L. Urban).

Ben, E.S., 2008. Teknologi Tablet. Universitas Andalas, Padang.

Departemen Kesehatan Republik Indonesia, 2014. Farmakope Indonesia, edisi V. ed. Jakarta.

Febrianti, N., Irfan, Y., Risanti, D., 2012. Kandungan antioksidan asam askorbat pada jus buah-buahan tropis. Bioedukatika 9(1), 6-9.

Fitri, M., Andriani, Kawiji, 2012. Pengaruh konsentrasi etanol dan suhu spray dryer terhadap karakteristik bubuk klorofil daun alfalfa (Medicago sativa, L.) dengan menggunakan binder maltodekstrin. J. Teknosains Pangan Vol 1 No 1, 110-117.

Fonner, D.E., Anderson, N.R., Banker, C.S., 1981. Granulation and Tablet Characteristic in Lieberman, H.A., Lachman, L., (Eds.), Pharmaceutical Dosage Form: Tablet vol.2, Mer, New York 226-231.

Groos, J., 1991. Pigments in vegetable, Chlorophylls and Carotenoids. Van Nostrand Reinhold, New York.

Hadisoewignyo, L., Fudholi, A., 2013. Sediaan Solida. Pustaka Belajar, Yogyakarta.

Hasanah, U., 2018. Menentuan kadar vitamin c pada mangga kweni dengan menggunakan metode iodometri. J. Kel. Sehat Sejah. 16(31), 1693-1157.

Huang, Y.C., Chang, Y.H., Shao, Y.Y., 2006. Effects of genotype and treatment on the antioxidant activity of sweet potato in Taiwan. Food Chem. 98 529-538. https://doi.org/https://doi.org/10.1016/j.foodchem.20 05.05.083.

Husni, A., Deffy, R.P., Iwab, Y.B.L., 2014. Aktivitas antioksidan padinas sp. pada berbagai suhu dan lama pengeringan. JPB Perikan. 9(2), 165-173.

Ighodaro, O.M., Akinloye, O.A., 2018. First line defence antioxidants-superoxide dismutase (SOD), catalase (CAT) and glutathione peroxidase (GPX): Their fundamental role in the entire antioxidant defence grid. Alexandria J. Med. 54, 287-293. https://doi.org/http://doi.org/10.1016/j.ajme.2017.09. 001

Ipci, K., Öktemer, T., Birdane, L., Altintoprak, N., Nuray Bayar Muluk Desiderio Passali, Lopatin, A., Bellussi, L., Mladina, R., Pawankar, R., Cingi, C., 2016. Effervescent tablets: a safe and practical delivery system for drug administration. Contin. Educ. Sci. Res. Assoc. 6(1), 46-50.

Lieberman, H.A., Leon, L., Schwartz, J.B., 1989. Pharmaceutical Dosage Forms : Tablet Volume 1.

Nariswara, Y., Hidayat, N., Effendi, M., 2013. Pengaruh waktu dan gaya tekan terhadap kekerasan dan waktu larut tablet effervescent dari serbuk wortel (Daucus carota, L.). J. Ind. 2(1), 27-35.

Natalia, Y., 2011. Pengaruh jenis dan konsentrasi penstabil terhadap mutu minuman klorofil daun kacang tujuh jurai (Phaseolus lunatus, L.). Skripsi Univ. Andalas, Padang.

Nazwa, F., Azrina, A., 2017. Comparison of vitamin C content in citrus fruits by titration and high 
performance liquid chromatography methods. Int. Food Res. J. 24(2), 726-733.

(HPLC)

Pourreza, N., 2013. Phenolic compounds as potential antioxidant. Jundishapur J. Nat. Pharm. Prod. Vol. 8, No.4, 149-150.

Pratiwi, G., Hertiana, T., 2013. Optimasi komposisi sukrosa dan aspartam sebagai bahan pemanis pada formula tablet effervescent ekstrak etanolik buah mengkudu, in: Majalah Obat Tradisional. Fakultas Farmasi, Universitas Gadjah Mada, Yogyakarta.

Rohmat, N., Ibrahim, R., Riyadi, P.H., 2014. Pengaruh perbedaan suhu dan lama penyimpanan rumput laut Sargassum polycystum terhadap stabilitas ekstrak kasar pigmen klorofil. 3(3), 118-126.

Rori, M.W., Yamlean, P. V, Sri, S., 2016. Formulasi dan evaluasi sediaan tablet ekstrak daun gedi hijau (Albemoschus manihot) dengan metode granulasi basah. J. Ilm. Farm. 5(2), 243-250.

Sandrasari, D.A., Abidin, Z., 2011. Penentuan konsentrasi natrium bikarbonat dan asam sitrat pada pembuatan serbuk minuman anggur berkarbonasi (effervescent). J. Teknol. Ind. 21(2), 113-117.

Suhery, W.N., Dan, A.F., Giovanni, B., 2016. Perbandingan metode granulasi basah dan kempa langsung terhadap sifat fisik dan waktu hancur orally disintegrating tablets (ODTs) piroksikam. J. Sains Farm. Klin. 2(2), 138-144.

Syamsia, Pratiwi, R.D., Susana, 2017. Sifat fisik tablet dihydroartemisinin-piperaquin (DHP) sediaan generik dan sediaan dengan nama dagang yang beredar di kotamadya jayapura. PHARMACON J. Ilm. Farm. -UNSRAT Vol.6, 310-314.

Syukri, Y., Wibowo, J.T., Herlin, A., 2018. Pemilihan bahan pengisi untuk formulasi tablet ekstrak buah mahkota dewa (Phaleria macrocarpa Boerl). J. Sains Farm. Klin. 5(1), 66-71.

Zheng, Y., Shi, J., Pan, Z., Cheng, Y., Zhang, Y., Li, N., 2014. Effect of heat treatment, $\mathrm{pH}$, sugar concentration, and metal ion addition on green color retention in homogenized puree of Thompson seedless grape. LWT -Food Sci. Technol. Vol 55, 595-603.

Zulfri, M., Syuhada, A., Hamdani, 2012. Kaji eksperimental sistem pengering hibrid energi suryabiomassa untuk pengering ikan. Jurnal Teknik Mesin Pascasarjana Universitas Syiah Kuala. Universitas Syiah Kuala, 1(1), 1-7. 